УДК 378

DOI $10.21661 / r-541123$

\title{
А.Б. Перцев
}

\section{ПРОФЕССИОНАЛЬНО-ОРИЕНТИРОВАННАЯ ПОДГОТОВКА ВОЕННЫХ КАДРОВ}

Аннотация: наиболее распространенной конщепџией подготовки военных специалистов является концепџия совершенствования профессиональной выучки и непрекращающегося обучения офищеров. Суть этой концепщии заключатся в том, что на протяжении всей своей службы офицер проходит через многоуровневую систему подготовки и переподготовки, что позволяет ему не только сохранять полученные на первоначальном этапе знания и навыки, но и развивать и совершенствовать их. В статье раскрыты как положительные стороны, так и противоречия и недостатки современной системы подготовки военных специиалистов.

Ключевые слова: профессионально-подготовленный, креативно-акмеологическое мышление, система подготовки военных кадров, военно-профессиональная деятельность.

\section{A.B. Pertsev}

\section{PROFESSIONAL-ORIENTED TRAINING OF MILITARY PERSONNEL}

Abstract: the most common concept of military specialists training is the concept of improving the professional continuous training of officers. The essence of this concept is that throughout their service, the officers go through a multi-level system of training and re-training, which allows them not only to preserve the knowledge and skills they obtained at the initial stage, but also to develop and improve them. This article reveals both positive aspects and contradictions and shortcomings in the modern system of training military specialists.

Keywords: professionally trained, creative-acmeological thinking, military personnel training system, professional military activity. 
Современная система подготовки военных кадров, наряду с позитивным опытом, традициями и имеющимся педагогическим потенциалом, несет в себе противоречия и недостатки, которые не обеспечивают ее соответствия с задачам развития Вооруженных Сил РФ в сложившийся в мире политической обстановке.

Современной, мобильной и профессионально-подготовленной Российской армии необходимы офицеры с развитым креативно-акмеологическим мышлением, направленным на защиту отечества и созидающе преобразующую деятельность. Однако в настоящее время возможности традиционных форм и методов обучения будущих офицеров ограничены, они не могут обеспечить опережающее развивающее обучение, направленное на развитие созидающего менталитета. К тому же, они недостаточно ориентированы на развитие творческого мышления и самостоятельности курсантов.

Таким образом, имеет место несоответствие системы подготовки военных кадров современным требованиям, продиктованным демократизацией и гуманитаризацией общества. Оно выступает как противоречие между современными требованиями к профессиональной подготовке офицера и сложившейся реальной практикой этой подготовки. Это приводит к тому, что, с одной стороны, в полной мере не реализуется потенциал каждого курсанта, с другой - у будущих офицеров не формируется самостоятельность и ответственность за принятие решений в сложных военных ситуациях.

В настоящее время наше общество переживает сложный и ответственный этап своего развития, связанный с перестройкой всех сторон общественной жизни. В этих условиях повышение роли человеческого фактора в экономической и социальной жизни страны обусловливает усиление внимания к профессионально важным качествам личности. Одним из ведущих среди них является профессиональная ответственность.

Вопрос об ответственном отношении человека к своему труду, к своим семейно-бытовым, социальным и гражданским обязанностям никогда не снимался с повестки дня нашего общества. 
В условиях службы в Вооруженных Силах вопросы профессиональной ответственности актуальны как никогда. Сложная экономическая и социально-политическая ситуация в стране негативным образом отражается на процессах жизнедеятельности и реформирования Вооруженных Сил России, решающая роль в которых принадлежит офицерскому корпусу. Сознание офицеров подвержено воздействию множества отрицательных социогенных факторов, значительно снижающих ответственность и эффективность военно-профессиональной деятельности.

Как показала практика, ответственное поведение личности не формируется само по себе по мере роста общеобразовательного, культурного уровня и даже социальной активности личности. Человека нельзя заставить действовать ответственно, не всегда помогают жесткая регламентация, карательные санкции, не дали должного эффекта и многочисленные призывы, не всегда оказывала воздействие воспитательная работа, направленная на развитие чувства ответственности за порученное дело.

Чтобы эффективно и целеустремленно решать эту задачу необходимо применять личностно-деятельностный подход в обучении курсантов, систематически изучать, оценивать и прививать им умения и навыки, также необходимо определять степень сформированности профессиональной ответственности, вследствие чего возникает потребность в разработке методики для выявления этого качества. Мотивация профессиональной деятельности поможет привитию ответственности в образовательном процессе и определению ее структуры, необходимых параметров и связей с другими личностными характеристиками, с которыми она коррелирует и представляет собой один из путей психологического анализа деятельности курсантов военных училищ. Данная проблема связана также с социальной, личностной, практической, теоретической и методологической значимостью данного качества у будущих офицеров и недостаточной изученностью ее психологических предпосылок, основных показателей, способов становления и связи с другими личностными качествами. 
Мотивация профессиональной деятельности будущих офицеров имеется в структуре образовательного пространства училища, которая имеет следующие принципы:

- уникальность и универсальность каждого человека;

- фундаментальный и системный подход;

- профессионализация - ориентация учебных дисциплин в военно-профессиональной деятельности будущего офицера;

- профессиональная компетентность;

- зависимость мотивации от влияния образовательной среды;

- саморазвития и самоорганизации личности.

Построить в высшей военной школе целостную систему мотивации профессиональной деятельности будущих офицеров, позволяющей реализовать конкретные мотивационный потенциал образовательного пространства вуза, представляется как поиск эффективных путей и средств совершенствования основных компонентов образовательного пространства.

Решение проблемы мотивации профессиональной деятельности будущих офицеров во время обучения в училище планируется через реализацию комплексной программы психолого-педагогического сопровождения процесса мотивации профессиональной деятельности курсантов, а также теоретической и методологической подготовки командиров подразделений, преподавателей и кураторов к осуществлению психолого-педагогического сопровождения процесса формирования у курсантов мотивации профессиональной деятельности.

Наиболее важным компонентом всеобъемлющей программы является подготовка программы мотивации профессиональной деятельности курсантов. Сам тренинг мотивации профессиональной деятельности включает в себя личный и профессиональный мотивационные модули, в содержании которых находятся относительно самостоятельные исследования и упражнения, объединенные в одну программу. Также важным является тот факт, что обучение может быть проведено с помощью таких форм, как игры, упражнения или минисеминары с обучаемыми. 
Говоря о профессионально-ориентированной подготовке военных кадров в училище, необходимо отметить, что существующая система подготовки военных кадров для Вооруженных сил Российской Федерации требует от профессорско-преподавательского состава эффективного, профессионального и целеустремленного решения задач по применению личностно-деятельного подхода к обучению курсантов, необходимо систематически изучать, оценивать и прививать навыки к военной профессии, а также определять степень сформированности, профессиональной ответственности за созидающе преобразующую деятельность и развивать креативно-акмеологическое мышление курсантов, направленное на защиту Отечества.

\section{Список литературы}

1. Маклаков А.Г. Общая психология: учебник. - СПб.: Питер, 2012. - 583 с.

2. Матюшкин А.М. Методы проблемного обучения и границы их применения. - Казань, 1979.

3. Психологический словарь / под ред. В.П. Зинченко, Б.Г. Мещерякова. - 3е изд., перераб. и доп. - М., 2013. - 440 с.

4. Приказ МО РФ от 12.10.16 г. №655 «Об организации работы с личным составом в ВС РФ».

5. Федеральный закон от 29.12.2012 №273-Ф3 «Об образовании в Российской Федерации».

6. Семененко Н.Н. Становление профессиональной ответственности у курсантов военных училищ Сухопутных войск: автореф. дис ... канд. психол. наук. M., 1998 [Электронный ресурс]. - Режим доступа: http://naukapedagogika.com/psihologiya-19-00-14/dissertaciya-stanovlenie-professionalnoyotvetstvennosti-u-kursantov-voennyh-uchilisch-suhoputnyh-voysk-1 (дата обращения: 18.05.2020).

\section{References}

1. Maklakov, A. G. (2012). Obshchaia psikhologiia., 583. SPb.: Piter.

2. Matiushkin, A. M. (1979). Metody problemnogo obucheniia i granitsy ikh primeneniia. Kazan'. 
3. Zinchenko, V. P., \& Meshcheriakova, B. G. (2013). Psikhologicheskii slovar'., 440. M.

4. Prikaz MO RF ot 12.10 .16 g. 655 "Ob organizatsii raboty s lichnym sostavom v VS RF".

5. Federal'nyi zakon ot 29.12.2012 273-FZ "Ob obrazovanii v Rossiiskoi Federatsii".

6. Semenenko, N. N. (1998). Stanovlenie professional'noi otvetstvennosti u kursantov voennykh uchilishch Sukhoputnykh voisk: avtoref. dis. M. Retrieved from http://nauka-pedagogika.com/psihologiya-19-00-14/dissertaciya-stanovlenie-professionalnoy-otvetstvennosti-u-kursantov-voennyh-uchilisch-suhoputnyh-voysk-1

Перцев Александр Борисович - канд. полит. наук, полковник, начальник факультета, ФГКВОУ ВО «Дальневосточное высшее общевойсковое командное училище имени Маршала Советского Союза К.К. Рокоссовского», Благовещенск, Россия.

Pertsev Alexandr Borisovich - candidate of political sciences, colonel, head of faculty, Far East Higher Combined Command Military School named after Soviet Union Marshal K.K. Rokossovsky, Blagoveshchensk, Russia. 